\title{
Information Technology Resources and Innovation Performance in Higher Education
}

\author{
https://doi.org/10.3991/ijim.v15i04.20193
}

\author{
Galih Abdul Fatah Maulani $(\bowtie)$, Nizar Alam Hamdani, Sukma Nugraha, \\ Asri Solihat, Teten Mohamad Sapril Mubarok \\ Universitas Garut, Garut, Indonesia \\ galihafmeuniga.ac.id
}

\begin{abstract}
Information technology encourages various forms of organizations to always adapt to changes so that they can sustain their business for a long time. Higher education institutions are organizational entities required to use information technology to support existing business processes. This study aims to examine the extent to which information technology resources have an influence on innovation performance in higher education. Quantitative research methods are used to determine this influence by involving 97 respondents who work in higher education institutions in Garut, Indonesia, besides processing and modeling research using SmartPLS. The results of the analysis show that information technology resources have an essential role in creating innovation performance improvement in higher education institutions, especially in terms of product innovation. The research was conducted only at private universities in Garut Regency. Therefore, further research involving universities in a nationwide scope is recommended. The results of this study imply that it is necessary for universities, which are expected to be ready for changes, to involve information technology in the creation of innovation in order for them to survive. The effect of information technology resources on the performance of innovation in private universities in Garut Regency has never been studied before; therefore, we consider that our study provides a novel contribution to the field.
\end{abstract}

Keywords - Information Technology Resources, Innovation Performance, Higher Education Institutions

\section{Introduction}

Every organization is expected to maintain its existence in the competitive business environment [1]. The current global conditions require every organization of all types, including universities, to be able to adapt to dynamic environmental changes (Maulani \& Hamdani, 2019). It takes innovative endeavors for universities to face global competition [3]-[5]. In this regard, information technology becomes indispensable and contributes to the current development of globalization [6], [7]. Technology is part of a good business strategy for organizations, including universities, to maintain their existence in global competition [8]-[10]. 
Higher Education Institutions in Indonesia currently have the largest number in the Southeast Asian region. Every year, the number of universities in Indonesia continues to grow. This indicates that quality competition is there between them. [2]. Therefore, several universities, especially those that are private, must have a business strategy in their organization [5], [7], and it is necessary to be equipped with sufficient resources for this strategy to run optimally. At present, the total number of higher education institutions in Indonesia registered with ministries, both public and private, is 3,276. Higher education institutions (HEI) are spread throughout Indonesia but geographically most concentrated in Java (Maulani \& Hamdani, 2019).

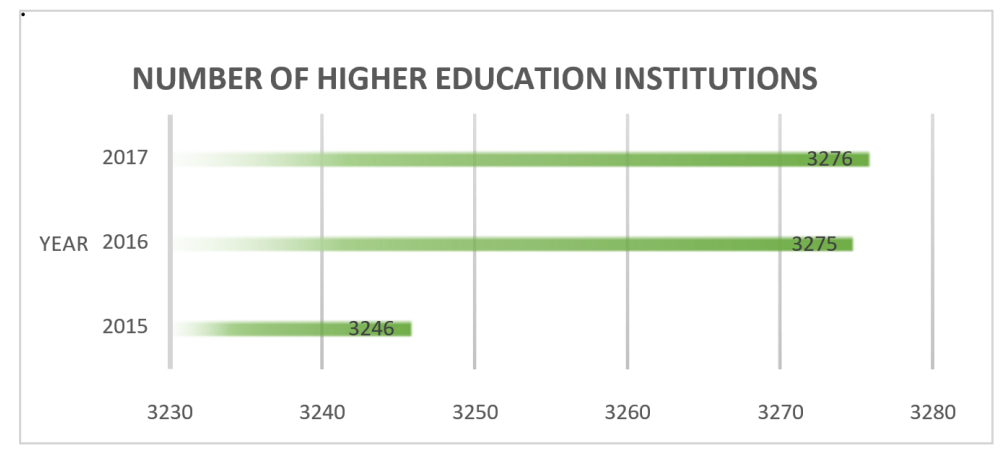

Fig. 1. Growth in the number of universities in Indonesia in 2015 - 2017 (12)

Given the increasingly fierce competitive environment, innovation becomes one of the many factors important in creating a competitive advantage [12]. Information technology can be one of the competitive applied in higher education institutions. However, private universities are built upon independent resources with limited innovation creation value. Private universities are characterized by their dependency on tuition payments. This dependency restricts their innovation performance that requires investment in information technology [5], [13]. This study seeks to examine the influence of information technology resources on the innovation performance of universities.

\section{$2 \quad$ Literature Review}

Previous studies suggest that innovation performance refers to the achievement of innovation by an organization that carries out organizational activities in fulfilling their desired and measurable targets [14], [15]. Universities can encourage innovation performance by using a variety of technologies from which they gain benefits [16]. Innovation performance can be seen from the way organizations introduce new technologies to encourage the development of new services. This can create a dynamic and flexible environment that can improve innovation performance [17], [18]. Innovation performance can be measured through product Innovation [16], [19] and process innovation [14], [20], [21]. 
Information technology has an important role and strategic position in the success of achieving the competitive advantage of private universities in Indonesia (Maulani \& Hamdani, 2019). The role of information technology becomes strategic, and it becomes a resource of universities in maintaining its existence. Information technology can be optimal provided that its resources are well managed. These resources include information technology relations resources, information technology human resources and information technology infrastructure [22], [23].

\section{$3 \quad$ Methodogy}

This study was conducted using a verification approach. Data were collected from 97 respondents working in higher education institutions located in Garut, Indonesia. These respondents were selected using a non-probability sampling technique. Data analysis was performed using PLS-SEM. Table 1 present the studied variables.

Table 1. Research Variables

\begin{tabular}{|l|l|}
\hline \multicolumn{1}{|c|}{ Variables } & \\
\hline \multirow{3}{*}{ Information Technology Resources (X) } & IT infrastructure \\
\cline { 2 - 2 } & Resource (X1) \\
\cline { 2 - 2 } & IT human resource (X2) \\
\cline { 2 - 2 } Innovation Performance (Y) & IT relationship resource (X3) \\
\hline \multirow{2}{*}{ Product Innovation (Y1) } \\
\cline { 2 - 2 } & Process Innovation (Y2) \\
\hline
\end{tabular}

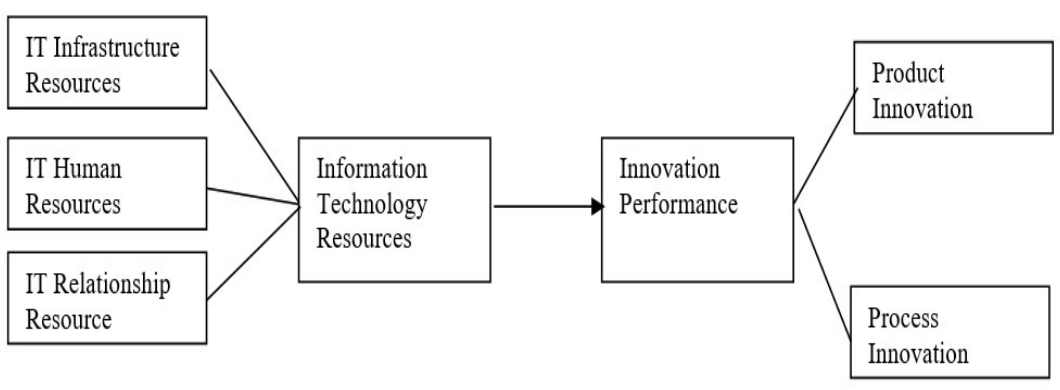

Fig. 2. Research Model

\section{$4 \quad$ Results and Findings}

The impact of information technology resources on innovation performance in private higher education institutions is calculated and analyzed using SmartPLS. Fig. 3 presents the resulting modeling. 


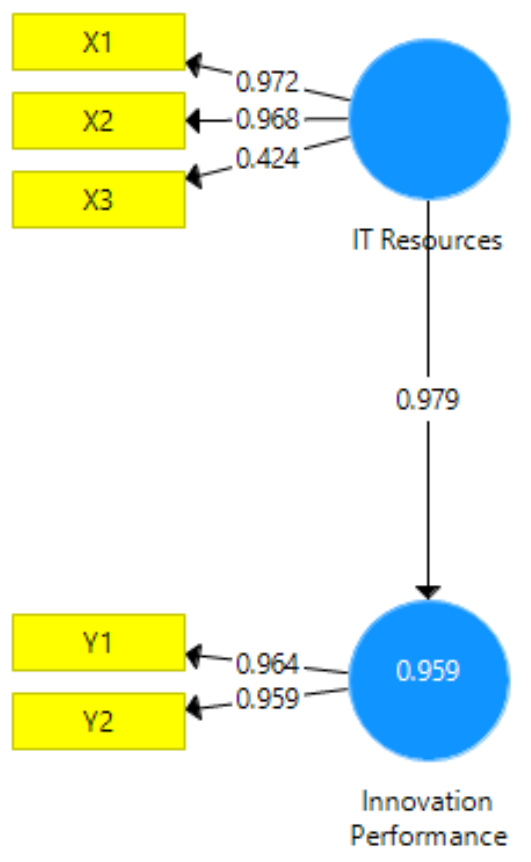

Fig. 3. PLS Modelling

Fig. 3 shows that the coefficient value between information technology resources and innovation performance is 0.979 , meaning that the influence of information technology resources on innovation performance of private universities is 0.979 . In addition, Fig. 3 shows the following:

1. The factor loading values of indicators of information technology resources $(X)$ are as follows: the factor loading value of information resources (X1) is 0.972 , of information human resources (X2) is 0.968 , and of information technology relationship resources (X3) is 0.434 .

2. The factor loading values of indicators of innovation performance $(\mathrm{Y})$ are as follows: the factor loading value of product innovation (Y1) is 0.964 and of process innovation (Y2) is 0.959 .

An indicator is stated reliable if its factor loading value is above the suggested value of 0.50 . Since the variable information relationship resources (X3) does not meet this requirement, this indicator is removed from the PLS modeling. SmartPLS also showed the following results. 


\begin{tabular}{|c|c|c|c|c|c|c|c|c|}
\hline \multirow[t]{2}{*}{ 葍 Matrix } & 措帮Cronbac & h's Alpha & 掫草 rho_A & 泹直 Composit & te Reliability & f灌 Aver & erage Variance Extracted ... & Copy to $\mathrm{Cl}$ \\
\hline & & \multicolumn{2}{|c|}{ Cronbach's Alpha } & rho_A & \multicolumn{2}{|c|}{ Composite Reliability } & \multicolumn{2}{|c|}{ Average Variance Extracted (AVE) } \\
\hline \multicolumn{2}{|c|}{ IT Resources } & & 0.749 & 0.947 & & 0.856 & & 0.687 \\
\hline \multicolumn{2}{|c|}{ Innovation Performance } & & 0.918 & 0.921 & & 0.961 & & 0.924 \\
\hline
\end{tabular}

Fig. 4. Construct Reliability and Validity Matrix

A variable is said to be valid if its Average Variance Extracted (AVE) value is above the suggested value of 0.50 .

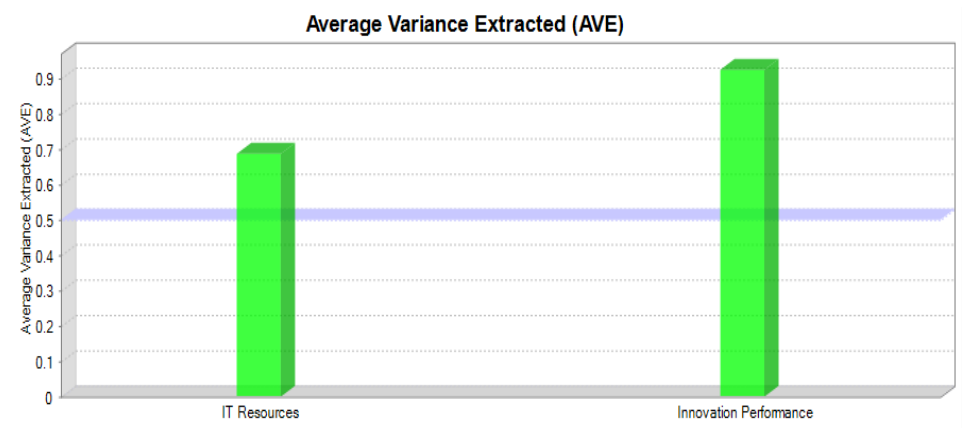

Fig. 5. Average Variance Extracted (AVE)

The results of the SmartPLS calculation show that all studied variables are valid. The variable information resources has an AVE value of 0.687 , and the variable innovation performance has an AVE value of 0.924. A variable is also stated reliable if its composite reliability and Cronbach's alpha values are above 0.7. Fig. 4 shows that the composite reliability value of innovation performance is 0.961 and of information technology resources is 0.856 . The Cronbach's alpha value of innovation performance is 0.918 and of information technology resources is 0.749 . It could be concluded that both variables are valid and meet the research requirement.

Then the analysis continues with testing the structural model (inner model). This is done by looking at the R Square, which is a goodness of fit test.

\section{R Square}

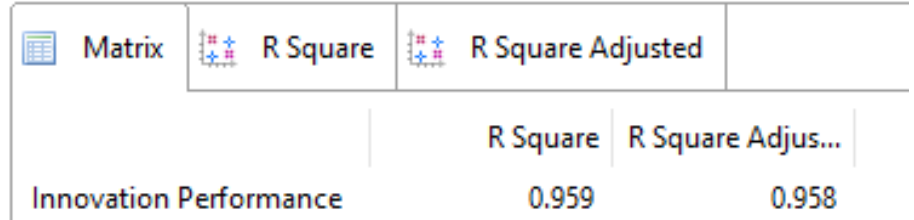

Fig. 6. R Square 
Fig. 6 shows that the R-Square value is 0.959 , meaning that information technology resources contribute to innovation performance as much as $95 \%$, and the other $5 \%$ is influenced by factors other than the studied variable.

To find out how significant the influence of information technology resources on innovation performance is, the bootstrapping was performed and the results are as follows.

\section{Path Coefficients}

\begin{tabular}{|c|c|c|c|c|c|c|c|}
\hline \multirow[t]{2}{*}{ Mean, STDEV, T-Values, P-Val... 届 } & Confidence Intervals & 同 Confidence Inte & vals Bias $\mathrm{CO}_{\ldots}$ & Samples & Copy to Clipboard: & Excel Format & RForn \\
\hline & Original Sample (0) & Sample Mean (M) & Standard De & viation (STDEV) & TStatistics (10/STDEV & \multicolumn{2}{|c|}{ PV Values } \\
\hline IT Resources -> Innovation Performa & 0,990 & 0.991 & & 0.004 & 220.86 & & .000 \\
\hline
\end{tabular}

Fig. 7. Patch Coefficients

The original sample value of 0.990 in Fig. 7 shows that the relationship between information technology resources and innovation performance is positive, indicating that an optimal use of information technology resources can encourage innovation performance in universities. The T statistics value of 220.867 is higher than the critical value of 1.96, meaning that the influence of information technology resources on the innovation performance of private universities in Indonesia is very significant.

These results confirm that IT Resources has a strategic role in improving Innovation performance, as well as the findings of previous studies [24], [25]. IT Resources can move business unit entities or work units in organizations where components such as IT Human Resources relating to the ability of staff or leaders in using IT, IT Infrastructure Resources that play a role in the availability of IT supporting facilities and IT Resources Relationships refers to the relationship between IT and business units or work units, which reflects the level of mutual trust and commitment in sharing risks and responsibilities [22].

\section{Acknowledgement}

This research work is supported by Faculty of Entrepreneurship, Universitas Garut. - Indonesia.

\section{References}

[1] N. A. Hamdani and G. A. F. Maulani, "Motivation and leadership on the performance of private higher education lecturers," in Advances in Business, Management and Entrepreneurship, London: Taylor \& Francis Group, LLC, 2020, pp. 812-816. https://doi.org/10.1201/9780429295348-172

[2] G. A. F. Maulani and N. A. Hamdani, "The Influence of Information Technology and Organizational Climate on the Competitiveness of Private Universities in Indonesia," Int. J. 
Recent Technol. Eng., vol. 8, no. 1S, pp. 142-145, 2019, [Online]. Available: https://www.ijrte.org/download/volume-8-issue-1s/.

[3] I. Nonaka and A. Y. Lewin, "Dynamic Theory Knowledge of Organizational Creation," Organ. Sci., vol. 5, no. 1, pp. 14-37, 1994, doi: 10.1287/orsc.5.1.14.

[4] A. Sokol, A. Gozdek, I. Figurska, and M. Blaskova, "Organizational Climate of Higher Education Institutions and its Implications for the Development of Creativity," Procedia Soc. Behav. Sci., vol. 182, pp. 279-288, 2015, https://doi.org/10.1016/j.sbspro.2015.04. $\underline{767}$

[5] G. A. F. Maulani and N. A. Hamdani, "Perencanaan Strategis Sistem Informasi pada Perguruan Tinggi Swasta di Indonesia (Studi Kasus pada Institut Pendidikan Indonesia Garut)," J. PETIK, vol. 4, no. September, pp. 162-166, 2018, https://doi.org/10.31980/ ipetik.v4i2.367

[6] K. Matthews, C. Garratt, and D. Macdonald, "The Higher Education Landscape: Trends and Implications," no. May, pp. 1-10, 2018, [Online]. Available: https://espace.library.uq.edu.au/data/UQ 68d8c9a/UQ68d8c9a_OA.pdf?Expires=1536424 039\&Signature $=$ BfkRFENvbqYynOFSi-1OYx71ZKsN8rEkaQ4eQDty47CzHOY3MAMEi6Dt50skvxoC0wIGzmBSeG1T06BDuoJTXctdTk2wToISI-Fd8d1nUgNaGAUpLgg8sTf9EVMTUEjH3T70Lj9SkfsbxB3v9kcQ1xJWGvzWcW.

[7] N. A. Hamdani and S. Nugraha, "The influence of information technology and entrepreneurial orientation on competitiveness and business performance," in Advances in Business, Management and Entrepreneurship, London: Taylor \& Francis Group, LLC, 2020, pp. 565-569. https://doi.org/10.1201/9780429295348-118

[8] N. A. Hamdani and W. Susilawati, "Application of Information System Technology and Learning Organization to Product Innovation Capability and Its Impact on Business Performance of Leather Tanning Industry," Int. J. Eng. Technol., vol. 7, pp. 393-397, 2018. https://doi.org/10.14419/ijet.v7i2.29.13661

[9] [9] N. A. Hamdani and G. A. F. Maulani, "The Influence Information Technology Capabilities and Differentiation on the Competitiveness of Online Culinary SMEs," Int. J. Recent Technol. Eng., vol. 8, no. 1S, pp. 146-150, 2019.

[10] A. Hamdani and G. A. Fatah, "Perencanaan Strategis Sistem Informasi pada Usaha Kecil dan Menengah," vol. 4, no. September, pp. 167-172, 2018. https://doi.org/10. 31980/jpetik.v4i2.382

[11] G. A. F. Maulani and N. A. Hamdani, "Can universities improve their competitiveness using information technology?” Int. J. Eng. Adv. Technol., vol. 8, no. 6 Special Issue 3, pp. 456-458, 2019, https://doi.org/10.35940/ijeat.f1083.0986s319

[12] M. Ghasemaghaei and G. Calic, "Assessing the impact of big data on firm innovation performance: Big data is not always better data," J. Bus. Res., vol. 108, no. September 2019, pp. 147-162, 2020, https://doi.org/10.1016/j.jbusres.2019.09.062

[13] A.-P. Pavel, "Global University Rankings - A Comparative Analysis," Procedia Econ. Financ., vol. 26, no. 15, pp. 54-63, 2015, https://doi.org/10.1016/s2212-5671(15)00838-2

[14] F. Shahzad, G. Y. Xiu, and M. Shahbaz, "Organizational culture and innovation performance in Pakistan's software industry," Technol. Soc., vol. 51, pp. 66-73, 2017, https://doi.org/10.1016/j.techsoc.2017.08.002

[15] C. López-Nicolás and Á. L. Meroño-Cerdán, "Strategic knowledge management, innovation and performance," Int. J. Inf. Manage., vol. 31, no. 6, pp. 502-509, 2011, https://doi.org/10.1016/j.ijinfomgt.2011.02.003

[16] L. Statsenko and G. Corral de Zubielqui, "Customer collaboration, service firms' diversification and innovation performance," Ind. Mark. Manag. no. December 2018, pp. 1-17, 2019, https://doi.org/10.1016/j.indmarman.2019.09.013 
[17] M. Zhang, Y. Qi, Z. Wang, X. Zhao, and K. S. Pawar, "Effects of business and political ties on product innovation performance: Evidence from China and India," Technovation, vol. 80-81, no. September 2016, pp. 30-39, 2019, https://doi.org/10.1016/j.technovation. 2018.12.002

[18] C. K. Padilha and G. Gomes, "Innovation culture and performance in innovation of products and processes: a study in companies of textile industry," RAI Rev. Adm. e Inovação, vol. 13, no. 4, pp. 285-294, 2016, https://doi.org/10.1016/j.rai.2016.09.004

[19] V. Ramadani, R. D. Hisrich, H. Abazi-Alili, L. P. Dana, L. Panthi, and L. Abazi-Bexheti, "Product innovation and firm performance in transition economies: A multi-stage estimation approach," Technol. Forecast. Soc. Change, vol. 140, no. December, pp. 271-280, 2019, https://doi.org/10.1016/j.techfore.2018.12.010

[20] A. Mardani, S. Nikoosokhan, M. Moradi, and M. Doustar, "The Relationship Between Knowledge Management and Innovation Performance," J. High Technol. Manag. Res., vol. 29, no. 1, pp. 12-26, 2018, https://doi.org/10.1016/j.hitech.2018.04.002

[21] J Hong, Y. Liao, Y. Zhang, and Z. Yu, "The effect of supply chain quality management practices and capabilities on operational and innovation performance: Evidence from Chinese manufacturers," Int. J. Prod. Econ., vol. 212, no. January, pp. 227-235, 2019, https://doi.org/10.1016/j.ijpe.2019.01.036

[22] H. Mao, S. Liu, J. Zhang, and Z. Deng, "Information technology resource, knowledge management capability, and competitive advantage: The moderating role of resource commitment," Int. J. Inf. Manage., vol. 36, no. 6, pp. 1062-1074, 2016, https://doi.org/10. 1016/j.ijinfomgt.2016.07.001

[23] N. Ismaeel, R. Siron, I. Zahari, and M. Khalid, "Impact of Information Technology Infrastructure on Innovation Performance: An Empirical Study on private Universities in Iraq," vol. 39, no. November 2015, pp. 861-869, 2016, https://doi.org/10.1016/s2212$\underline{5671(16) 30250-7}$

[24] C. Mark, A Handbook of Information Technology, First Edit. New Delhi: Global Media, 2009.

[25] S. M. M. R. Naqvi and S. Bashir, "IT-expert retention through organizational commitment: A study of public sector information technology professionals in Pakistan," Appl. Comput. Informatics, vol. 11, no. 1, pp. 60-75, 2015, https://doi.org/10.1016/j.aci.2011. $\underline{11.001}$

\section{$7 \quad$ Authors}

Galih Abdul Fatah Maulani is a lecturer at Faculty of Entrepreneurship, Universitas Garut, Indonesia. His research interests include business information system, strategic management, technopreneurship and information technology. Email: galihafm@uniga.ac.id

Nizar Alam Hamdani is a lecturer at Faculty of Economy Universitas Garut. His research interests include strategic management, knowledge management, entrepreneurship, and SMEs.

Sukma Nugraha is a lecturer at Faculty of Entrepreneurship, Universitas Garut, Indonesia. His research interests include Entrepreneurship, Human Resource Management and Strategic Management. 
Asri Solihat is a lecturer at Faculty of Entrepreneurship, Universitas Garut, Indonesia. His research interests include Financial Management, Accounting, Marketing and Entrepreneurship.

Teten Mohamad Sapril Mubarok is a lecturer at Faculty of Entrepreneurship, Universitas Garut, Indonesia. His research interests include Human Resource Management, Strategic Management and Education.

Article submitted 2020-11-27. Resubmitted 2021-01-03. Final acceptance 2021-01-10. Final version published as submitted by the authors. 